\title{
Masculinity in Traditional Medicine Advertisements for Men's Strength on Mass Media: Multimodality Analysis
}

\author{
Nani Darmayanti ${ }^{1}$, Dadang Suganda ${ }^{1}$, Lina Meililinawati ${ }^{1}$ \\ ${ }^{I}$ Faculty of Cultural Sciences. Universitas Padjadjaran Bandung - Sumedang Km. 21 Jatinangor 40353 \\ *Corresponding Author: Nani Darmayanti, Faculty of Cultural Sciences. Universitas Padjadjaran \\ Bandung - Sumedang Km. 21 Jatinangor
}

\begin{abstract}
This research studies particular factors relating to masculnity construction in traditional medicine advertisements for men's strength on mass media. The multimodality theory used in the researchwas Systemic Functional Linguistics by Halliday (2004) explaining language metafunction into ideational, interpersonal, and textual. Analysizing advertisements strcuture used the theory by Cheong (2004). Meanwhile, analyzing the masculinity construction used the theory by Connell (1987) on hegemonic masculinity. The model of multimodality analysis used was themodel developed by the combination of multimodality theories by (Anstey $\&$ Bull, 2010) and Kress and Van Leeuwen (1996-2006). The data of the research were traditional medicine advertisements for men's strength collected from H. Suhendar Medical Klinik and published on daily newspaper in various reegions in Indonesia. The research aims at (1) analyzing the advertisement structure and metafunction conveyed in the advertisement of H. Suhendar Medical Clinic and (2) revealing masculinity construction implied in the advertisement of H. Suhendar Medical Clinic. The result shows (1) there are complete advertisement structure and metadiscoure consisting of Announcement, Enhancer, Particiant, Demand, Setting, and Call and Visit Information, (2) the multimodality analysis result on H. Suhendar Medical Clinic has constructed the definition of masculinity namely great men must have long big, hard, and last longer vitality in order to be loved by the wives and may keep harmonious family.
\end{abstract}

Keywords: Multimodality Metafunction, Masculinity, Advertisement

\section{INTRODUCTION}

Masculinity is one of the topics that is often discussed on studies relating to gender discourse. Masculinity is a stereotype of men contested with feminism as women's stereotype. Masculinity and femininity are two opposite polars and form a straight line in which each point describes the degree of manliness (masculinity) or womanliness (femininity). A man having identical characteristic to masculinity stereotype is regarded a masculine man, if the characteristic is much more it is called a supermasculine man if less it is called a less masculine or feminine man. (Darwin: 1999).

The masculinity construction in each individual may differ and is heavily influenced by its social and cultural background. In other words masculinity is not a concept with single category dimension. The concept can be varied among the society, social class, and level of civilization. This suggests that masculinity is a social construction which may be defined differently by each member of society. By realizing that masculinity is a multidimensional concept, there are some spaces for us to deconstruct and reconstruct the concept.

The masculinity construction is getting more interesting when produced and spread through media. Piliang (in Ibrahim and Suranto, 1998) considers mass media as an arena of 'sign struggle'. Media are the arena of position struggling, between the positions of 'seeing' (active) and 'being seen' (passive). It is the 'sign' that is being struggled reflecting particular image. In this image, the value of masculinity is more dominant than the femininity placed in marginal position. It means that there has been struggling 'sign hegemony, particularly 'gender hegemony' on mass media.

An interesting phenomenon happening lately in Indonesia society is the spread of commercial advertisements regarding masculinity issue, namely traditional medicine advertisement relating to medical treatment for men's strength. These advertisements spread through various printed media which may take even a whole page of newspaper both printed and online versions. The traditional 
medicine advertisements on strength are suspected to deliver an ideology that Connell (1987) calls as hegemonic masculinity (Kimmel, 2005:30). Hegemonic masculinity, explained by Connell (1987), is a form of dominant masculinity which culturally is often considered as the most valued and becomes the learning base to become 'a true man" (Kimmel, 2005:30)

One of the advertisements theming medicines for men's strength and spread on various mass media in Indonesia is the advertisement of $\mathrm{H}$. Suhendar Clinic. Based on the information on its web http://www.klinikhajisuhendar.com, it is revealed that the H. Suhendar Clinic is an alternative medical clinic for men's vital. The clinic at first is located in PekayonBekasi. Up to this day, it has 14 branch offices spread across Indonesia. The opening of these branches is under the consideration of many patients that need medical treatment. One of the treatments is massage accompanied by taking herbal medicine which they call as "Ramuan Tanah Pasundan"(Potion of Pasundan Region)

\section{RESEARCH OBJECTIVE}

The brief explanation above shows that among men, masculinity, strength medicine, and media has become a complex issue and affected each other. Therefore, it is quite interesting to be studied on how the masculinity constructions are in medical clinic advertisements for men's strength spread on mass media. Considering the data source of the research are advertisements, therefore they need to be described first regarding the advertisements ' structure and also verbal and visual signs conveyed in the advertisements by using multimodality analysis theories. Afterwards, the result of the multimodality analysis is used as the foundation in revealing the masculinity construction implied in the advertisements.

\section{MeThOdOLOGY}

This research used descriptive-qualitative method. The theory used was Multimodality Discourse Analysis of Systemic Functional Linguistics by Halliday (2004). The multimodality analysis model was developed from the combination of multimodality theories by (Anstey \& Bull, 2010) and Kress and Van Leeuwen (1996-2006). To analyze the advertisements' structure used the theory by Cheong (2004). Meanwhile, in analyzing the masculinity construction, the theory by Connell (1987) on hegemonic masculinity was applied. The data were collected from various mass media containing the advertisements of $\mathrm{H}$. Suhendar Traditional Medical Clinic.

\section{THEORITICAL BACKGROUND}

Norris (2004) in Sinar (2012) states that all interactions are multimodality. The multimodality analysis emphasizes on all communication means as playing important roles both verbal and nonverbal because language has meaning, content or informative essence.

O'Halloran and Smith in Sinar (2012) argue that multimodality analysis includes all kinds of communication possessing interaction and integration texts of two or more semiotic sources or communication means to achieve the communicative function of the text.

Multimodality is a term used to refer to the way people communicate by using different modes at the same time (Kress and Van Leeuwen, 1996). Kress and Van Leeuwen (2006), and Machin and Myer (2012) believe that messages delivered through different semiotic modes at the same time (verbal and visual) in a text cannot be analyzed by only the linguistic analysis tools, but also must use two different analysis tools, namely linguistics and visual analysis which support each other in order to understand the whole meanings.

The multimodality used in the research came from the Systemic Functional Linguistics (SFL) theory by Halliday. In the perspective of Systemic Functional Linguistics (SFL), language is a system of meaning and other (that is a form and expression to realize that meaning).

Halliday states that each language study is based on an approach. It means that there is no language study which is free from the basic value or presumption (Halliday, 1994: xvii). This study is based on two basic concepts differentiating SFL from other linguistic branch, namely (a) language is a social phenomenon taking form as social semiotic and (b) language is a construal text (co-determining and referring) with social context. Therefore, language study cannot be separated from social context (Saragih, 2006:1). 
Furthermore, Saragih (2006: ii) explains that the SFL theory determine that language possesses three functions in life, namely describing, exchanging and forming experiences. These three functions are called language metafunction. Halliday (1994: 179) mentions three components of the functions as ideational (describing), interpersonal (exchanging), textual (texts in forming experiences) functions.

Anstey and Bull (2010) explain that a text is called multimodality if that text is formed from two or more combinations of semiotic systems. According to them, there are five multimodality semiotic systems in a text namely: 1) Linguistics, consisting of aspects such as vocabulary, generic structure and grammar of written and oral language, 2) Visual, consisting of aspects such as colors, vector, perspective on animate and inanimate objects, 3) Audio, consisting of aspects such as volume, highlow tone, musical rhythm and sound effects, 4) Gesture, consisting of aspects such as movements, speed, silence, in facial expressions and body language, 5) Location, consisting of aspects such as distance of objects' location, directions, positions from layout, and distance settings based on layout.

To find out the meanings conveyed in the advertisements, Cheong (Sinar, 2012: 136) explains the advertisements' structure consisting of verbal, visual and both combined.

a) Announcement gives three explanations that announcement is the only message of the advertisement, the most important aspect interpersonally among other messages in the text, and catch phrase aspect.

b) Enhancer is to build and modify meaning from the interaction between Lead and Announcement. The enhancer message in the advertisement is usually delivered through paragraph.

c) Call and Visit Information is an information contact accessible to users who want to know more about the products and it usually is printed in small fonts and its position is under or above or left or right side of the products' advertisement.

d) Lead explains size, position, or colors which potentially coveys impression and meaning for users.

e) Display functions to describe products in real and explicit means. The component of visual display congruent functions to realize products without symbolization and display incongruent realizes products through symbolization..

f) Emblem consists of visual emblem realized through advertised product's logo, and linguistic emblem is formed through brand name or trademark. The emblem function gives identity or status to product located on any side accordingly to the advertisement text proportion.

g) Tag is the recommendation toward the advertised products.

h) Conversion in text explains active and passive participants in verbal text..

i) Setting functions as background to explain the products' excellence offered

j) Additive is the relationship explaining various visual information through verbal text which is complete each other excellence possessed by the products.

k) Demand is the direct interaction between participants and public realized through eye contact looking at viewers badalah interaksi langsung antara pastisipan dengan khalayak diwujudkan melalui kontak mata atau eye contac yang menatap kepada penyaksi.

1) Social and Equality are the means of visual elements collecting in the text by giving information to the public that the products may be possessed easily and its realization can be found on Call and Visit Information.

m) Salience shows the excellence gained by using the advertised products, indirectly delivering the effects to the public, for instance beautiful body is the dream for every woman.

n) Reactor are neighboring people looking at the object which becomes the attention center.

5. Data Analysis

\subsection{The Advertisements' Structure and Metafunction of H. Suhendar Clinic Advertisement}

The following is the display of $\mathrm{H}$. Suhendar Clinic advertisement. The advertisement with the exact same format and text content was published also on other newspapers in various regions across 
Indonesia. The specified advertisement displayed in this research is the advertisement published in Palembang Pos Daily (2017).

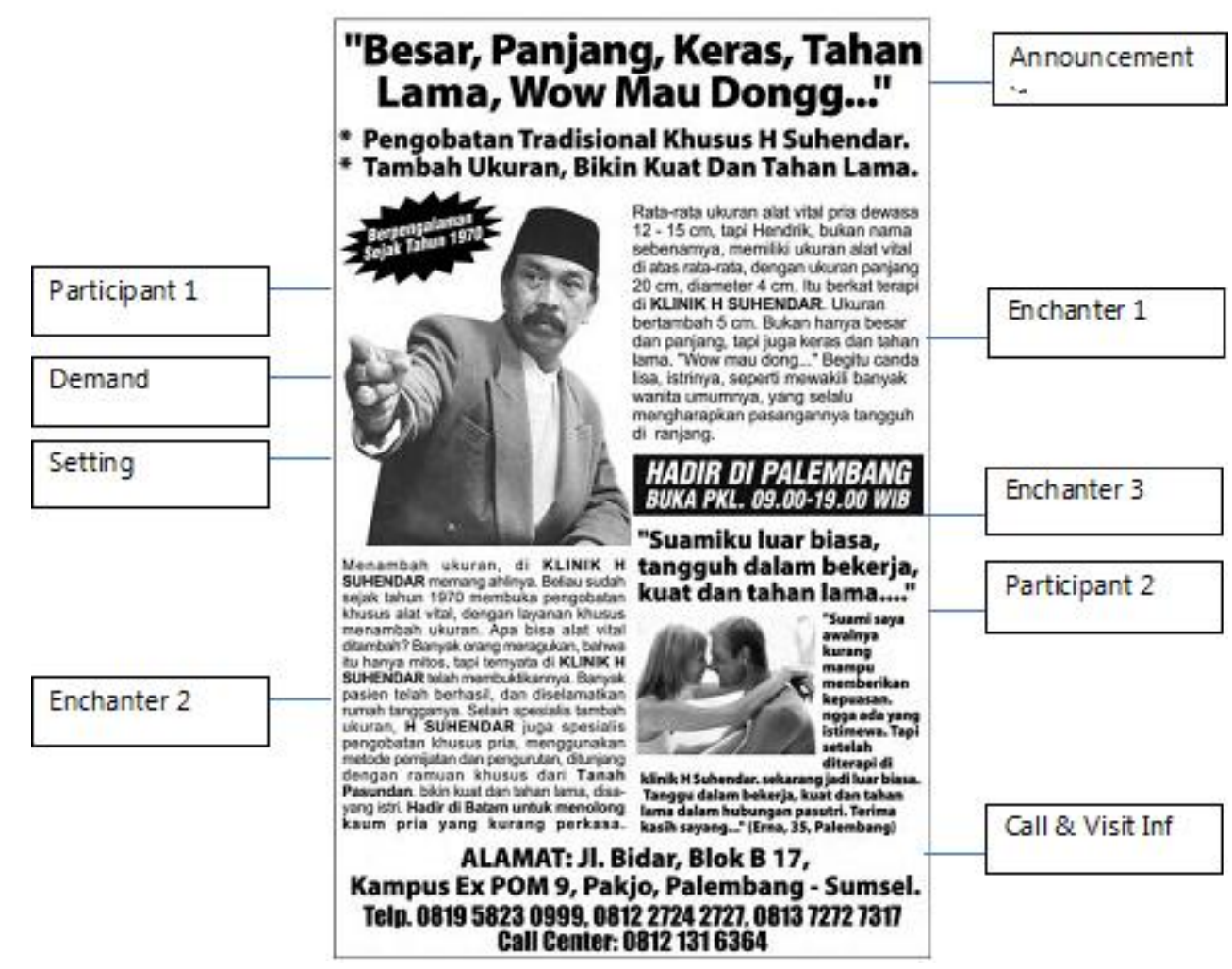

Generally, the advertisements which become the data for the research are dominated by verbal sign and additional visual sign. The visual sign in the medicine advertisements for men's strength is marked by Participant 1 and 2. Participant 1 is exhibited by a man named H. Suhendar as well as the owner of the H. Suhendar Medical Clinic. He is considered 50-60 years old, wearing suit, black Kopiah(fez), bushy black mustache, straight forward look, wearing stone ring with hand movement also straight forward..

Meanwhile, Participant 2 is exhibited by a couple of man and woman with European look texture, looking at each other, sticking each other's nose. The woman puts her hands on the man's neck (hugging), while the man puts his hands on the woman's waist. The verbal sign in this advertisement spreads in parts of the advertisement namely Announcement, Enhancer 1, Enhancer 2, Enhancer 3, Participant, Demand, Setting, and Call and Visit Information.

\subsubsection{Announcement}

The process occurred in announcement of H. Suhendar Clinic Advertisement is divided into primary and secondary processes. The primary announcement is the main message manifesting in the process of relational: Besar, Panjang, Keras, dan Tahan lama (Big, Long, Hard and Last longer), and the possessive relational: Wow Mau Dongg... (Wow I want). The sentence is the direct quote spoken by one of the patients' wife that has sought medical treatment to H. Suhendar Clinic. The announcement emphasizes its message to the men/women customers who are wanting the same thing as the direct quote through topical theme delivered.

Meanwhile, the secondary announcement: Pengobatan Khusus H. Suhendar(H. Suhendar Special Medical Treatment) and Tambah Ukuran, Bikin Kuat danTahan Lama (make bigger, stronger and last longer) are direct marketing message, namely information about place and function of the information delivered in the advertisement.

\subsubsection{Enhancer 1}

The ideational function of Enhancer 1 in the advertisement of H. Suhendar Clinic shows the succeed patients seeking medical treatment to $\mathrm{H}$. Suhendar Clinic. The text is produced with descriptive 
strategy and direct quote from the succeed patients getting medical treatment at $\mathrm{H}$. Suhendar Traditional Medical Clinic.

"Rata-rata ukuran alat vital pria dewasa 12-15 cm, tetapi Hendrik, bukan nama sebenarnya memiliki ukuran alat vital di atas rata-rata, dengan ukuran panjang $20 \mathrm{~cm}$, diameter $4 \mathrm{~cm}$. Itu berkat terapi di Klinik H. Suhendar. Ukuran bertambah $5 \mathrm{~cm}$. Bukan hanya besar dan panjang, tetapi juga keras dan tahan lama. "Wow mau dong..." begitu canda Lisa, istrinya, seperti mewakili banyak wanita umumnya, yang selalu mengharapkan pasangannya tangguh di ranjang.

"The average size of adult male vital is $12-15 \mathrm{~cm}$, but Hendrik, not the real name, has size above the average with the long $20 \mathrm{~cm}$, diameter $4 \mathrm{~cm}$. This thanks to the therapy at $\boldsymbol{H}$. Suhendar Clinic. The size get bigger by $5 \mathrm{~cm}$. Not only big and long, but also hard and last longer. "Wow I want.." said Lisa, his wife, as representing many other women in general, who always hope his partner stronger on bed.

\subsubsection{Enhancer 2}

The ideational function of Enhancer 2 in the advertisement of $\mathrm{H}$. Suhendar Clinic shows the power of service and product worthy of consumers' choice as an alternative traditional medicine for men's strength. The interpersonal function of enhancer persuades and influences the readers of the advertisement to believe in what is delivered in the advertisement which also conveys values and socio-cultural society on the masculinity concept.

Menambah ukuran di klinik H. SUHENDAR memang ahlinya. Beliau sudah sejak tahun 1970 membuka pengobatan khusus alat vital, dengan layanan khusus menambah ukuran. Apa bisa alat vital ditambah? Banyak yang meragukan, bahwa itu mitos, tetapi ternyata di KLINIK H SUHENDAR telah membuktikannya. Banyak pasien telah berhasil dan diselamatkan rumah tangganya. Selain spesialis tambah ukuran, H SUHENDAR juga spesialis pengobatan khusus pria, menggunakan metode pemijatan dan pengurutan, ditunjang dengan ramuan khusus dari Tanah Pasundan. Bikin kuat dan tahan lama, disayang istri. Hadir di Batam untuk menolong kaum pria yang kurang perkasa.

Making bigger, H. SUHENDAR Clinic is the expert. He has practiced specified medical treatment for male's vital since 1970,with special service in making bigger. Can it be bigger? Many doubt, that it is a myth, by H. SUHENDAR CLINIC has proven otherwise. Many patients have succeeded and their household are saved. Beside specialized in making bigger, H. SUHENDAR also specializes in specified medicine for men, using massage method, supported with special potion of Tanah Pasundan (Pasundan region). Make stronger and last longer, loved by the wife. Now available in Batam to help less strength men.

Enhancer functions to explain the excellences possessed by the service offered as part of the annpouncement. The excellences are realized through material process: menambah (making bigger), membuktikan (proven), berhasil (succeeded), diselamatkan (saved) and menolong (help). This material process represents humans' experiences in getting services offered in the announcement and supported by mean circumstance: menggunakan metode pemijatan dan pengurutan, ditunjang dengan ramuan khusus dari Tanah Pasundan (using massage method, supported by special potion of Pasundan Region) and objective circumstance: Bikin Kuat dan tahan lama, disayang istri (Make stronger and last longer, loved by the wife).

\subsubsection{Enhancer 3}

The ideational function of Enhancer 3 in the advertisement of H. Suhendar clinic gives information that adds power/excellence of the service and product offered by $\mathrm{H}$. Suhendar Clinic. The interpersonal function of enhancer 3 is still the same as the previous enhancer, that is persuading and influencing the readers to believe in what is delivered in the advertisement. The strategy used in the enhancer 3 is direct quote from the patient's wife who ever sought medical treatment at H. Suhendar Clinic, namely Erna, 35 years old from Palembang.

"Suamiku luar biasa, tangguh dalam bekerja, kuat dan tahan lama...." "Suami saya awalnya kurang maтрu memberikan kepuasan. Nggak ada yang istimewa. Tapi setelah diterapi di 
klinik H. Suhendar, sekarang jadiluar biasa. Tangguh dalam bekerja, kuat dan tahan lama dalam hubungan pasutri. Terima kasih sayang..."

"My husband is amazing, hard-working, strong and last longer..." At first he gave less pleasure. Nothing special. But after getting therapy at H. Suhendar Clinic, now he's amazing. Hard-working, strong and last longer on bed. Thank you dear..."

The power or excellence of the service and product offered by H. Suhendar Clinic conveyed in the enhancer 3 is stated through time circumstance namely setelah terapi di Klinik H. Suhendar, sekarang jadi luar biasa (after getting therapy at H. Suhendar Clinic, now he's amazing) and objective circumstance, namely luar biasa (amazing), tangguh dalam bekerja (hard-working), kuat (strong), and tahan lama (last longer).

\subsubsection{Call and Visit Information}

Call and visit Information in the advertisement text of men's strength traditional medicine is the part under the advertisement that informs the address of the clinic in Batam City, namely Jl. Bidar, Blok B17 Kampus ExPOM 9, Pakjo, Palembang-Sumsel. Telp 081958230999, 081227242727, 081372727317 Call Center 08121316364

\subsection{The Masculinity Construction in the Advertisement of $\mathbf{H}$. Suhendar Clinic}

Based on the analysis of the traditional medicine advertisement for men's strength on mass media it shows that becoming "man' is harder than becoming "woman". Should some women are getting more efforts to always look beautiful by coming over to beauty clinic and consuming certain medicine, men must work harder. Men must bear the burden of the myth of strength. This myth built from advertisement discourse states that strength is identical to ideal man. To achieve this idealism, men are willing to consume medicines that the safety is not guaranteed

On the other side, advertisements on mass media offer pseudo-reality, dreams and all dreams are always great that those who dream are willing to make them come true. As long as they do not, consumers will always keep trying. This is where the capitalism becomes the spirit of the media and grows certain feelings of unstoppable satisfaction in the readers. The capitalism also demands masculinity roles in men's identity.

Therefore, great synergy happens between ideal hope of becoming strong men and advertisement on mass media. This hope is represented through advertisement. The bond is constructed to become a particular ideology that tries to define who the ideal man is as in the advertisement.

\section{CONCLUSION}

The result of multimodality analysis in the advertisement of H. Suhendar Medical Clinic shows that (1) there are advertisement's structure and multimodality semiotic system in the advertisement of $\mathrm{H}$. Suhendar Medical Clinic consisting of Announcement, Enhancer, Participant, Demand, Setting, and Call and Visit Information. Each of multimodality semiotic system profoundly correlates in producing advertisement meanings so that the messages produced are comprehensive and easily understood by the readers, (2) the multimodality semiotic system in H. Suhendar Medical Clinic advertisement has constructed the definition of masculinity, namely men must bear the burden of strength myth. This myth built by the advertisement discourse states that strength is identical to ideal man. To achieve this idealism, men are willing to consume unguaranteed medicines.

\section{REFERENCES}

[1] Anstey, Michèle danGeof Bull. 2010. "Helping Teachers to Explore Multimodal". Curriculum and Leadership Journal. Vol. 8 (16).

[2] Darwin, Muhadjir. 1999. "MASKULINITAS: Posisi Laki-Laki dalam Masyarakat Patriarkis" Hasil penelitian Center for Population and Policy Studies Gadjah Mada University S.281.

[3] Halliday, M.A.K dan Hasan, R. 1976. Cohession in English. London: Longman

[4] Halliday, M.A.K. 2004. An Introduction to Functional Grammar. Amerika Serikat: Oxford University Press

[5] Hermawan, Budi. "Multimodality:Menafsir Verbal Multimodality: Menafsir Verbal, Membaca Gambar, dan Memahami Teks". Journal bahasa \& sastra, Vol. 13, No.1, April 2013. 
[6] Ibrahim, Idi Subandy and Hanif Suranto, (1998). Wanita dan Media : Kontruksi ldeologi Gender dalam Ruang Publik Orde Baru. Bandung: Remaja Rosdakarya.

[7] Kurnia, Novi. 2014. Representasi Maskulinitas dalam Iklan. Yogyakarta: Pascasrjana Universitas Gadjah Mada.

[8] Lubis, A. Hamid. 1993. Analisis Wacana Pragmatik. Medan: FPBS IKIP Medan

[9] Matthiessen, Christian M.I.M et al. 2010. Key Term in Systemic Functional Linguistic. New York: Continuum International Publishing.

[10] Royce, Terry D. and Bowcher, Wendy L. Without Publication Year.New Directions in The Analysis of Multimodal Discourse. New Jersey: Lawrence Erlbaum Associate.

[11] Saragih, Amrin. 2006. Bahasa dalam Konteks Sosial. Medan: PPs Unimed.

[12] Sinar, Tengku Silvana. 2012. Teori \& Analisis Wacana Pendekatan Linguistik Sistemik Fungsional. Medan: Mitra

\section{AUTHOR'S BIOGRAPHY}

Nani Darmayanti is is lecturer of linguistics in Faculty of Cultural Sciences Universitas Padjadjaran. Her research interests are are critical discourse analysis, sociolinguistics, and pragmatics.

Dadang Suganda is lecturer of linguistics in Faculty of Cultural Sciences Universitas Padjadjaran. His research interests are are critical discourse analysis, sociolinguistics, and pragmatics.

Lina Meilinawati is is lecturer of literature in Faculty of Cultural Sciences Universitas Padjadjaran. Her research interests are are cultural science and literature.

Citation: Nani Darmayanti, Dadang Suganda, Lina Meililinawati. "Masculinity in Traditional Medicine Advertisements for Men's Strength on Mass Media: Multimodality Analysis." International Journal of Humanities Social Sciences and Education (IJHSSE), vol 5, no. 5, 2018, pp. 49-55.doi: http://dx.doi.org/10.20431 12349-0381.0505007.

Copyright: (C) 2018 Authors. This is an open-access article distributed under the terms of the Creative Commons Attribution License, which permits unrestricted use, distribution, and reproduction in any medium, provided the original author and source are credited. 